\title{
15. URANIUM SERIES DISEQUILIBRIUM AND ISOTOPE STRATIGRAPHY IN HYDROTHERMAL MOUND SAMPLES FROM DSDP SITES 506-509, LEG 70, AND SITE 424, LEG 54: AN ATTEMPT AT CHRONOLOGY ${ }^{1}$
}

\author{
Claude Lalou, Evelyne Brichet, Héloĩse Leclaire, and Jean-Claude Duplessy, Centre des Faibles Radioactivés, \\ Laboratoire Mixte CNRS-CEA, F.91190 Gif sur Yvette, France
}

\begin{abstract}
Use of the hydraulic piston corer during DSDP Leg 70 in the Galapagos mounds area allowed recovery of an undisturbed sedimentary sequence down to the basement. It thus became possible to establish the chronology of different events.

Several holes on and off the mounds were studied, using uranium series disequilibrium methods of age determination and oxygen isotope stratigraphy. The following sequence was thereby established:

1) From 600,000 to 300,000 years ago there was normal pelagic sedimentation, with an injection of uranium-rich solution, probably of hydrothermal origin, between 400,000 and 300,000 years ago.

2) From 300,000 to 90,000 years ago, nontronitic clay formed, replacing a pre-existing sediment.

3) From 60,000 to 20,000 years ago, manganese oxide deposits formed, probably also replacing pre-existing sediments.

4) About 19,000 years ago there occurred a uranium injection from seawater, attributed to the end of the hydrothermal circulation.

In some holes, especially Hole 424 , Leg 54 , younger manganese oxides have been found, indicating that some mounds may be presently active.
\end{abstract}

\section{INTRODUCTION}

The first extensive study of the Galapagos Spreading Center near $86^{\circ} \mathrm{W}$, where heat flow anomalies had been previously demonstrated (Sclater and Klitgord, 1973), began with the series of cruises of R/V Thomas Washington. From this work came numerous papers describing in detail the geophysical characteristics of the area, including: the first description of the mounds (Klitgord and Mudie, 1974), heat flow measurements on the northern flank of the spreading center (Sclater et al., 1974) as well as in the mounds area (Williams et al., 1974), and measurements of bottom water temperatures (Detrick et al., 1974).

The bathymetry of the area (Klitgord and Mudie, 1974) was determined with a deep-tow instrument package, which allowed mapping of chains of small mounds in an area 20 to $30 \mathrm{~km}$ south of the spreading center. The mounds are aligned parallel to the ridge and have been attributed to volcanism or, more probably, to thermal activity away from the central region. From the increase in sediment thickness with age of the crust, the authors determined a mean sedimentation rate of 5 $\mathrm{cm} / \mathrm{k} . \mathrm{y}$. The field of mounds is restricted to an elevated faulted area with a high heat flow, which suggests that mounds are hydrothermal vents (Williams et al., 1974). Anomalies of several hundredths degrees Celsius in the bottom waters above the spreading center were considered by Detrick et al. (1974) to be an important factor in creating deep water currents of more than $20 \mathrm{~cm} \mathrm{~s}^{-1}$,

\footnotetext{
${ }^{1}$ Honnorez, J., Von Herzen, R. P., et al., Init. Repts. DSDP, 70: Washington (U.S. Govt. Printing Office).
}

allowing renewal of bottom waters in the Panama Basin in fewer than 100 years.

The site was revisited in 1976 by R/V Melville for intensive bottom sampling, heat flow measurements, and a topographic survey for future submersible work (Lonsdale, 1977a). Bottom photographs and dredge hauls showed that the surface of at least some of the mounds was covered by an encrustation of Mn oxide directly resting on a nontronitic clay. A strong fractionation between iron and manganese is therefore observed, iron being restricted to an Fe-rich nontronite (Corliss et al., 1978, 1979). In the water above the mounds, a distinct increase of total dissolvable Mn was found, showing a maximum 5 meters above the sediment-seawater interface (Klinkhammer et al., 1977, in Corliss et al., 1978).

The novelty of such an extensive area of hydrothermal activity led the drilling ship Glomar Challenger to core these mounds during Leg 54. With conventional rock drilling equipment, the stratigraphy of soft formations is not preserved. However, the overall sequence of basalt, foraminiferal and nannofossil ooze (about 15 $\mathrm{m})$, nontronitic clay (about $15 \mathrm{~m}$ ), and a Mn-oxide layer was confirmed (Hekinian et al., 1978). The use of a hydraulic piston corer during Leg 70 allowed better recovery of an undisturbed sedimentary column, with the result that it is now possible to try to establish a radiometric chronology.

The three natural radioactive families ${ }^{238} \mathrm{U},{ }^{235} \mathrm{U}$, and ${ }^{232} \mathrm{Th}$ have proved useful in geochronological as well as geochemical studies of sediments. But since submarine hydrothermalism has been recognized only very recently as a possible worldwide phenomenon, the behavior of 
the different nuclides in the material resulting from this activity is not completely understood.

In the mounds area, the hydrothermal phenomenon has presumably lasted for the past 300,000 years (Natland et al., 1979), a time scale well suited for the uranium series disequilibrium methods of dating. Disequilibrium can be used in two ways:

1) The classical method of measuring sedimentation rates $(\mathrm{Ku}, 1976)$ in which the exponential decrease of unsupported ${ }^{230} \mathrm{Th}$ is used to derive a sedimentation rate. This unsupported ${ }^{230} \mathrm{Th}$ comes from dissolved uranium in seawater. It is obtained by subtracting the activity of ${ }^{234} \mathrm{U}$ from the total ${ }^{230} \mathrm{Th}$ activity. Uranium is considered to be present only in the detrital component of sediment which supports an equivalent activity of ${ }^{230} \mathrm{Th}$. Its usual concentration is around 1 to $3 \mathrm{ppm}\left(\mathrm{CaCO}_{3}\right.$ free). Foraminifers and coccoliths are uranium-poor (Holmes et al., 1968) as is biogenic silica $(\mathrm{Ku}, 1966)$. So, any significant departure from this value of 1 to $3 \mathrm{ppm}$ (on a detrital clay basis) could reflect a geochemical phenomenon.

2) A less classical use in deep sea sedimentation is based on the growth of ${ }^{230} \mathrm{Th}$ toward equilibrium with its parent ${ }^{234} \mathrm{U}$. This requires special geochemical environments in which authigenic phases, when formed, incorporated some uranium but no thorium. The method has been used successfully in dating corals. It has also been applied to the Mn-rich encrustations of the TAG (Scott et al., 1974) and FAMOUS areas (Lalou et al., 1977). In the latter area, the method failed because of the possible initial presence of ${ }^{230} \mathrm{Th}$ at the time of formation of the encrustation. Recently, studies of the $21^{\circ} \mathrm{N}$ East Pacific Rise sulfide deposits using this method seemed to give results in reasonable agreement with the geological setting (Lalou and Brichet, 1980a).

We have attempted to use the two methods in the Galapagos area in the hope that we may determine both the "age" of Mn-oxide encrustations found in the top layers of the sedimentary column, and the sedimentation rate (so as to supply information about the time scale of the post-hydrothermal event in the upper sedimentary sequence). In this sequence, a further verification of this time scale may be obtained using oxygen isotope stratigraphy in foraminifers (Shackleton and Opdyke, 1976).

Any disequilibrium found in all the sedimentary or hydrothermal sequences will be used in either way, to give limits for the chronology of these deposits.

\section{EXPERIMENTAL PROCEDURE}

\section{Radiochemistry}

Uranium and thorium isotopes were measured by alpha spectrometry, using either a solid state detector or an ionization chamber. About $500 \mathrm{mg}$ to $1 \mathrm{~g}$ of each sample were dried, weighed, and completely dissolved in an acid with addition of a spike (Ku, 1966). The spike used is a ${ }^{228} \mathrm{Th}$ solution in secular equilibrium with ${ }^{232} \mathrm{U}$. The added activity of the spike was generally $1.5 \mathrm{dpm}$ of ${ }^{228} \mathrm{Th}$. Uranium and thorium were separated and purified by coprecipitation, solvent extraction, ion exchange, and final extraction into 1- (2'-thenoyl)3,3,3-trifluoracetone (T.T.A.) in benzene. The deposition on stainless steel planchets was done through evaporation of the organic solution; thereafter, the planchet was made red-hot in order to burn away organic matter.

\section{Determination of Major Components}

Calcium carbonate content was determined volumetrically. X-ray dispersive analysis (EDAX) was used to determine aluminum in evaluating the detritic component using the ratio $\mathrm{Al} /$ clays $=8.4 \%$ (Turekian and Wedepohl, 1961); excess $\mathrm{Si}$ is attributed to biogenic silica.

\section{Isotope Analyses of Foraminifers}

Oxygen and carbon isotope analyses were performed on the planktonic species Globigerinoides ruber and the benthic genus Uvigerina, using a Micromass 602D mass spectrometer and following the procedure described by Duplessy (1978).

\section{SAMPLE DESCRIPTION}

In holes from mounds drilled on both legs, four main components may be distinguished from the basaltic basement to the top: (1) a pelagic foraminiferal and nanno calcareous ooze, referred to here as the basal sediment; (2) "hydrothermal" nontronite; (3) Mn-oxide crust fragments; and (4) a layer of foraminiferal, nannocalcareous, and siliceous ooze (referred to as the upper sediment).

The off-mound sedimentary sequence is much more uniform. The sedimentary cover is made up of siliceous and calcareous foraminiferal and nannofossil ooze, except in Hole 506D where a thin nontronite layer $(90 \mathrm{~cm}$ thick) is interbedded at about 5 meters from the top.

At Site 424, Leg 54, the upper part of the sequence (upper sediment and nontronitic clay) was poorly recovered, especially the upper sediment, which was mixed with hydrothermal mud. One exception is Hole 424B, where about 2 meters of upper sediment have probably been recovered. Chips of Mn oxide were randomly distributed at all depths in the cores.

On Leg 70, we chose to study material from moundHole $506 \mathrm{C}$ because it presents the whole sequence and is somewhat separated from Site 424 . To verify sedimentation rates by isotope stratigraphy, we chose off-mounds Hole 506D. Manganese-oxide crusts from Hole 509B were also studied because they were more numerous in this core.

Site 509 is at the same position as was Site 424 , whereas Site 506 is approximately $4 \mathrm{~km}$ northwest of it.

\section{RESULTS AND DISCUSSION}

\section{The Upper Sediment}

\section{A Radiochemical Model}

Results of the radiochemical analysis are given in Table 1 for Holes 424B and 506C. Biogenic silica as well as biogenic carbonates are a dilutant for uranium isotopes. Since there is a contribution of biogenic silica in these sediments, we preferred to normalize the results to the clay fraction rather than to calcium carbonate free values.

In Figure 1 we have plotted ${ }^{230} \mathrm{Th}_{\text {excess }}$ vs. depth in cores from Holes 424B (Fig. 1A) and 506C (Fig. 1B). (Filled circles are the measured values.) Hole 424B shows an approximately exponential decrease in excess ${ }^{230} \mathrm{Th}$. This is not the case for Hole 506C, where some of the samples even show ${ }^{230} \mathrm{Th}$ depletion. Such a situation has already been noted by Rydell et al., (1974) in the East 
Table 1. Radiochemical analyses in the upper sediments.

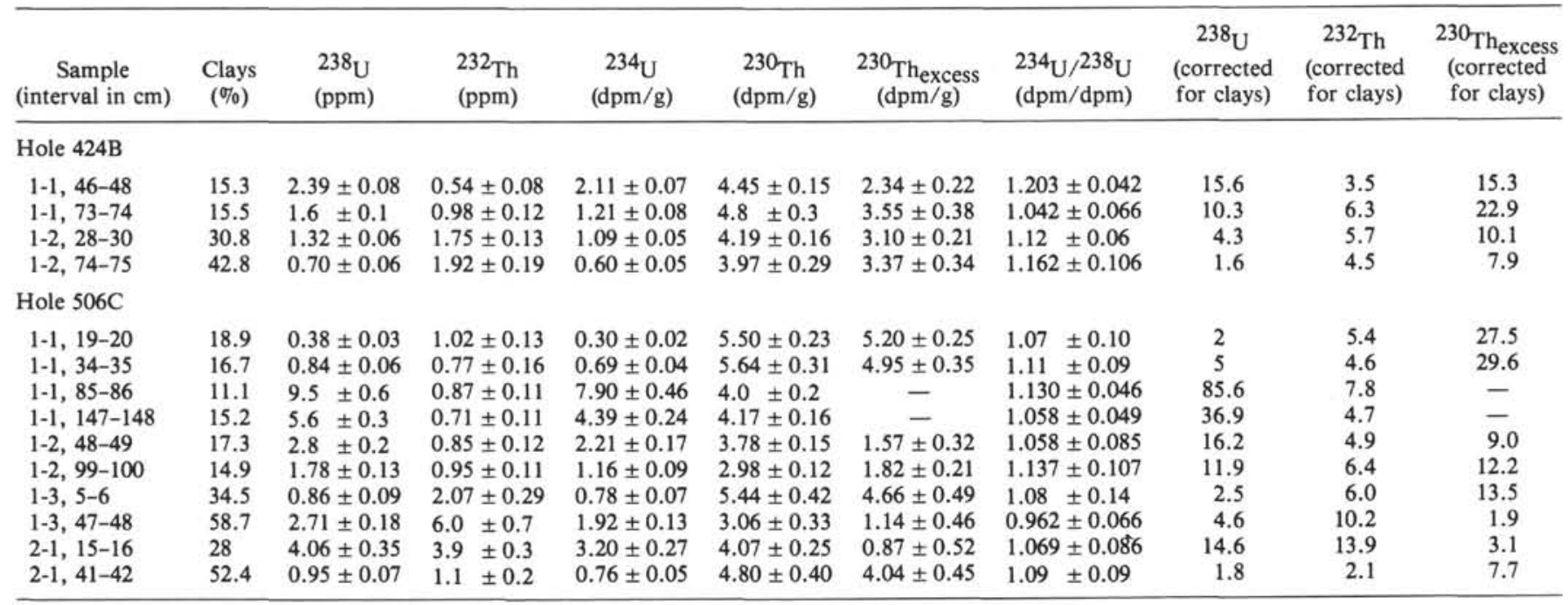
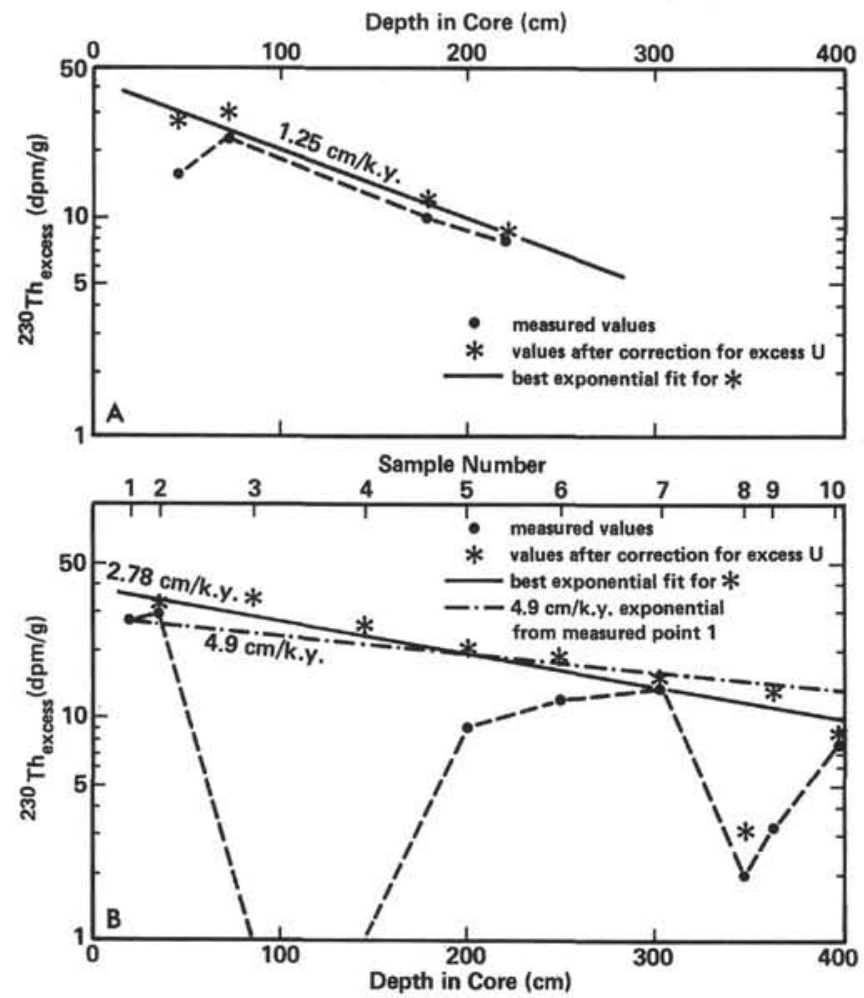

Figure 1. A. Excess ${ }^{230} \mathrm{Th}$ in the upper sediment of Hole $424 \mathrm{~B}$ as a function of depth in the core. B. Excess ${ }^{230} \mathrm{Th}$ in the upper sediment of Hole $506 \mathrm{C}$ as a function of depth in the core.

Pacific Rise sediments. It may be seen from Table 1 that, especially in Hole 506C, the lower values are associated with samples having a very high uranium concentration. As in the basal sediment at Site 424, we propose that an injection of uranium of either volcanogenic or seawater origin occurred after the deposition of the sediment (Lalou and Brichet, 1980b). This injection was not accompanied by thorium, as is shown by the very low
${ }^{232} \mathrm{Th}$ content of this core. A correction can be made as follows.

We used a mean value of $2 \mathrm{ppm} U$ for normal pelagic sediments in this area (Fisher and Boström, 1969) and subtracted this value from the total ${ }^{230} \mathrm{Th}$. The points so obtained (asterisks in Fig. 1) for Hole 506C as well as for Hole 424B show less scatter. The best-fit exponentials give a sedimentation rate of $1.25 \mathrm{~cm} / \mathrm{k} . \mathrm{y}$. for Hole 424B $(r=0.98)$ and $2.78 \mathrm{~cm} / \mathrm{k} . \mathrm{y}$. for Hole 506C $(r=$ 0.94 ). This correction does not account for the possibility that some ${ }^{230} \mathrm{Th}$ may have grown from the injected uranium. Such ${ }^{230}$ Th growth, however, may be significant at this level of uranium activity if the uranium was injected earlier than about 5,000 years. Therefore, the above values probably do not reflect the true sedimentation rates.

In order to find the age of this uranium injection and the true sedimentation rates we will use oxygen isotope stratigraphy.

\section{An Isotope Model}

The Late Quaternary time scale is well defined, at least for the last 150,000 years, by the down core ${ }^{18} \mathrm{O} /$ ${ }^{16} \mathrm{O}$ variations in foraminiferal tests. Oxygen isotope records reflect primarily isotope changes in the world ocean water resulting from the variation in volume of continental ice sheets. They display trends which are essentially independent of local effects. The oxygen isotope record has been divided into stages (Emiliani, 1955), the boundaries of which can generally be recognized in all oceans (Shackleton and Opdyke, 1973, 1976; Duplessy, 1978). The time scale for this record has been obtained by Broecker and $\mathrm{Ku}$ (1969), Broecker and Van Donk (1970), and Shackleton and Opdyke (1973). It has been confirmed by correlating the fine structure of Isotope Stage $5(77,000-127,000$ years ago) with the three sealevel highstands terraces $(82,000,100,000$ and 125,000 years ago) observed on the Barbados Island.

We did not have enough material to make this study on Hole 506C, so Hole 506D was used instead. Hole 
506D is an off-mounds hole, but it contains a $90-\mathrm{cm}$ thick layer of nontronitic clay. By means of the ${ }^{18} \mathrm{O} /{ }^{16} \mathrm{O}$ variations we may be able to:

1) Ascertain whether the off-mounds sedimentation was normal pelagic sedimentation or whether it resulted from slumping of higher parts of the mounds area.

2) Give an age limit to the nontronite deposit if the sedimentation was essentially regular.

3) Conclude either that there was slumping of this nontronite deposit or very rapid in situ formation, depending on whether there is a continuity of the oxygen isotope curve on both sides of the nontronite formation. If, on the other hand, the isotope record corresponding to the nontronite deposit is lacking, we can conclude that nontronitic clay replaced pre-existing sediment and give an upper and lower limit for its age.

The ${ }^{18} \mathrm{O} /{ }^{16} \mathrm{O}$ measurements made on the planktonic species Globigerinoides ruber are presented in Figure 2. The curve obtained is a typical isotope record. We may therefore conclude that:

1) In the upper sediment, sedimentation is normal, as seen from the easily recognizable major isotope stages; maximum $\delta^{18} \mathrm{O}$ values corresponding to Isotopic Stage 2 are found at $140 \mathrm{~cm}$ sub-bottom. Assuming an age of 18,000 years for the last glacial maximum (CLIMAP, 1976), we may calculate a sedimentation rate of 7.8 $\mathrm{cm} / \mathrm{k} . \mathrm{y}$. for the upper part of the core. Istope Stages 3, 4 , and 5a are clearly recorded. Assuming an age of 82,000 years for Stage $5 \mathrm{a}$, we can calculate a sedimentation rate of $4.8 \mathrm{~cm} / \mathrm{k}$.y. between 18,000 and 82,000 years ago.

2) In the sediment below the nontronitic clay, Stage $5 \mathrm{e}$ is clearly recorded at $700 \mathrm{~cm}$ sub-bottom. Below this, we have extended the isotope record through Glacial Stage 6. This stratigraphic framework is confirmed by the disappearance of pink-pigmented Globigerinoides

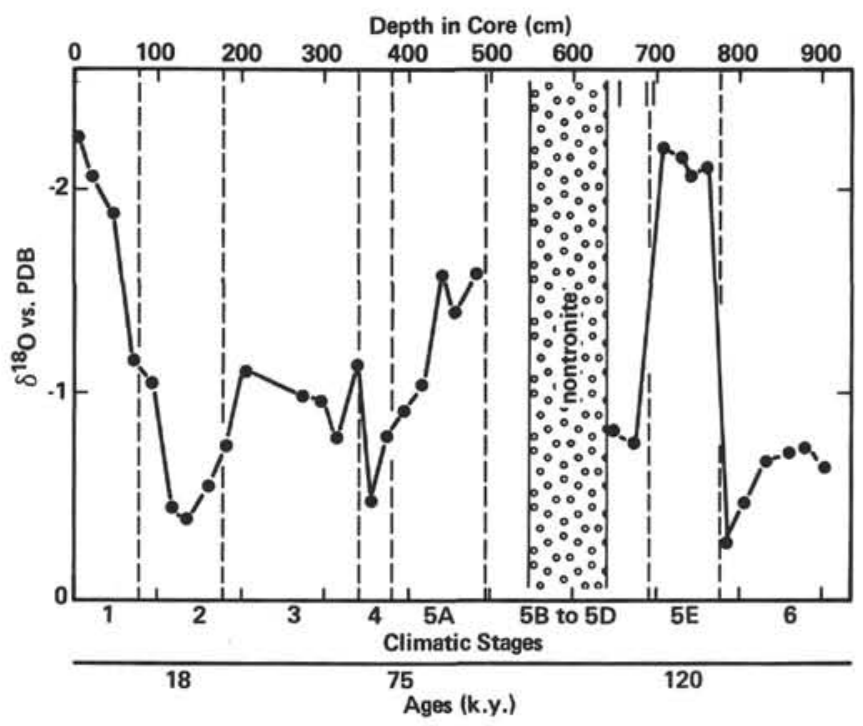

Figure 2. Oxygen isotope composition of the pelagic foraminifer Globigerinoides ruber in Hole 506D upon and below the nontronite layer. (Depth in the hole is indicated, as well as climatic stages deduced from the curve and corresponding ages.) ruber at the transition between Isotope Stages 5 and 6 (Thompson et al., 1979).

3) No foraminifers are present from the Isotope Substage $5 \mathrm{a} / 5 \mathrm{~b}$ transition (about 85,000 years ago) to mid5d Glacial Substage (about 110,000 years ago). This period corresponds in the core to a $50-\mathrm{cm}$ section sampled on board for organic carbon measurements and to $90 \mathrm{~cm}$ of the hydrothermal deposit. The basis of the hydrothermal deposit is then found in sediments deposited during Isotope Stage 5d. The age of the top of this nontronitic deposit cannot be accurately determined since we do not know whether the organic carbon sample was calcareous (most probably) or hydrothermal. We can give only an estimated age ranging from 85,000 years (nonrecovered hydrothermal sediment) to 95,000 years (nonrecovered calcareous sediment)-assuming that the sedimentation rate of the calcareous ooze has remained $4.8 \mathrm{~cm} / \mathrm{k} . \mathrm{y}$. in the lacking $50-\mathrm{cm}$ section.

In any case, no calcareous ooze deposited between $85,000 / 95,000$ years and 110,000 years before the present can be found in Core 506D, so we conclude that the hydrothermal deposit represents neither slumping nor chemical precipitation but rather a modification of preexisting sediment.

\section{Mixed Isotope and Radiochemical Model}

From the previously cited values, we are now able to quantify precisely the corrections necessary to understand the time sequence recorded by the radionuclides we studied.

For this, we make the assumption that the top of the nontronitic clay layer has the same age in the three holes, about 90,000 years. This leads us to a sedimentation rate of $4.9 \mathrm{~cm} / \mathrm{k} . \mathrm{y}$. for the $440 \mathrm{~cm}$ of sediments overlying the nontronite at Hole 506C. This is in good agreement with the sedimentation rate at Hole 506D and with the rates generally accepted for this region. For Hole 424B, an age of 90,000 years would lead to a somewhat lower sedimentation rate of $2.4 \mathrm{~cm} / \mathrm{k} . \mathrm{y}$., since only $210 \mathrm{~cm}$ of sediments were recovered overlying the nontronite. Since this hole is located in another mound field, one cannot be sure that the outset of nontronite deposition was contemporaneous in the various areas. Moreover, Hole 424B was cored by conventional rotary drilling; thus, the sequence could have been disturbed, and sections might be missing. Consequently we will limit our discussion to Hole 506C.

In view of the fact that the uppermost analyzed point of the core (Sample 506C-1-1, 19-20 cm) at $20 \mathrm{~cm}$ depth was not reached by the uranium injection, and has a normal uranium content ( $2 \mathrm{ppm})$, we may draw a line from this point, corresponding to a $4.9 \mathrm{~cm} / \mathrm{k}$.y. sedimentation rate (dashed-dot line, Fig. 1B). Some of the points indicated by asterisks are in agreement with this line: namely, points $5,6,7$ and 9 . The low value for point 10 may be explained by the special nature of the sediment at this level. It is highly enriched in manganese, and its clay content, like that of point 8 , is about three times higher than in the other samples. This implies a lower bulk sedimentation rate. 
The third, fourth, and fifth points from Hole $506 \mathrm{C}$ as indicated in Table 1 and Figure 3 are the most uranium enriched, and they show ${ }^{230} \mathrm{Th}$ in excess of that expected to fit the $4.9 \mathrm{~cm} / \mathrm{k}$.y. line. We may then assume that this excess ${ }^{230} \mathrm{Th}$ represents that formed in situ from the injected uranium. If this hypothesis is correct, the ${ }^{230} \mathrm{Th} /$ ${ }^{234} \mathrm{U}$ ratio may then give us an "age" for this uranium injection. The excess ${ }^{230} \mathrm{Th}$ for point 3 is $10.5 \mathrm{dpm} / \mathrm{g}$, for a ${ }^{234} \mathrm{U}$ excess of $61.5 \mathrm{dpm} / \mathrm{g}$; so the ${ }^{230} \mathrm{Th} /{ }^{234} \mathrm{U}$ ratio is 0.17 . For point 4 , the excess ${ }^{230} \mathrm{Th}$ is $3.9 \mathrm{dpm} / \mathrm{g}$ and the excess ${ }^{234} \mathrm{U} 25.6 \mathrm{dpm} / \mathrm{g}$, which gives a ${ }^{230} \mathrm{Th} /{ }^{234} \mathrm{U}$ ratio of 0.15 . A mean ratio of 0.16 corresponds to an age of about 19,000 years. As will be seen, this age is not in contradiction with the enrichment profile with depth.

The depth distribution of uranium in Hole $506 \mathrm{C}$ is given in Figure 3. It shows that the maximum value occurs at $84 \mathrm{~cm}$ depth. Given a mean sedimentation rate of $4.9 \mathrm{~cm} / \mathrm{k} . \mathrm{y}$., an age of about 17,000 years may be assigned to this level. So it is quite reasonable to think that uranium injection took place about 19,000 years ago and that the injection was mostly confined to near the sediment-water interface. A single episodic event may quite well account for the distribution of uranium with a well-defined peak.

With less precise chronological markers, a similar approach allowed Rydell et al. (1974) to conclude for East Pacific Rise sediments that there had been an injection of uranium 90,000 to 110,000 years ago in a sediment deposited about 350,000 years ago. Such uranium concentrations have also been found by Pisias (1976) to disturb the excess ${ }^{230} \mathrm{Th}$ chronology in the Panama Basin (core $\mathrm{Y} 69-106 \mathrm{P}$ at $2^{\circ} 59^{\prime} \mathrm{N}, 86^{\circ} 33^{\prime} \mathrm{W}, 2870 \mathrm{~m}$ depth) Pisias ascribed the uranium excess to reducing condi-
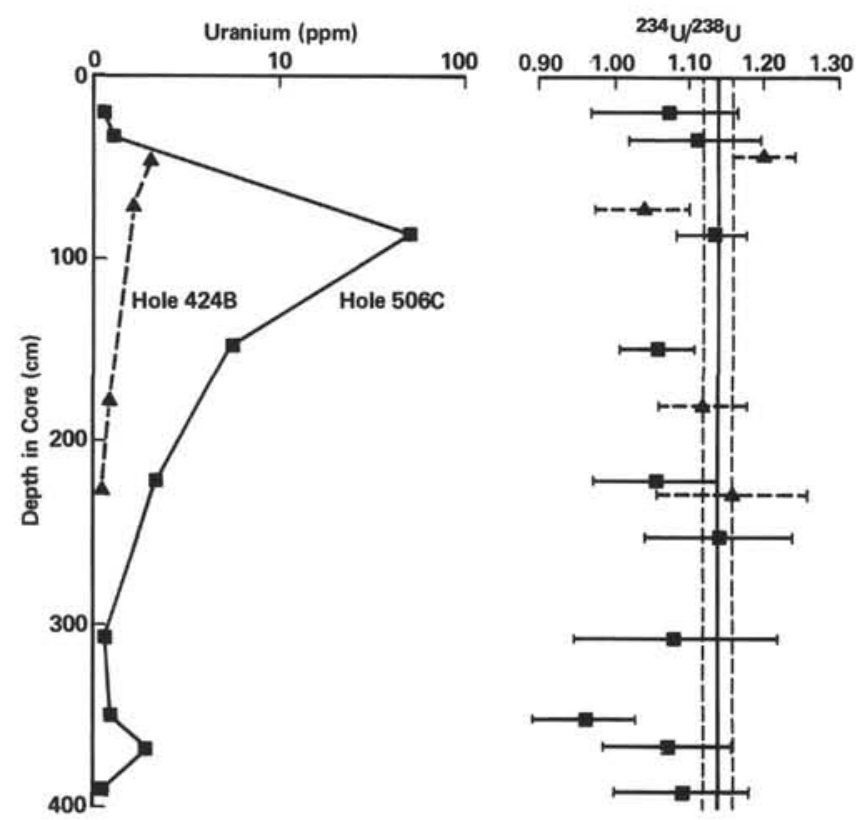

Figure 3. Left, distribution of uranium in the upper sediment (triangles for Hole 424B, squares for Holes 506C). Right, variations of the ${ }^{234} \mathrm{U} /{ }^{238} \mathrm{U}$ ratio in the same samples. (The values of present seawater uranium, $1.14 \pm 0.02$, is represented by the full line, with the two dashed lines as limits of variation.) tions, but he did not attempt to quantify the uranium input.

We will now discuss several possibilities for the origin of this uranium. Anomalous uranium concentrations have been found in other areas near or on active ridges, frequently associated with metalliferous sediments (Fisher and Boström, 1969; Ku, 1969; Bender et al., 1971; Turekian and Bertine, 1971; Veeh and Boström, 1971; Rydell and Bonatti, 1973; Dymond and Veeh, 1975; Boström and Rydell, 1979; Lalou and Brichet, $1980 \mathrm{~b})$. When traverses across the ridges are made, a clear enhancement of uranium content is found in cores directly associated with the ridge system.

Anomalously high uranium concentrations have also been found in samples from anoxic environments present in fjords and continental slopes of the Gulf of California (Veeh, 1967), Gulf of Mexico (Mo et al., 1973), Black Sea (Rona and Joensuu, 1974), and Eastern Mediterranean (Mangini and Dominik, 1979).

Two principal origins in the hydrothermal environment of the Galapagos mounds must be considered: normal seawater and volcanic activity.

Until now, a seawater origin has generally been attributed to uranium enrichments presenting a ${ }^{234} \mathrm{U} /{ }^{238} \mathrm{U}$ ratio compatible with the $1.14 \pm 0.02$ ratio of seawater, taking into account its decrease with time. When higher ratios are encountered, they are attributed to a volcanogenic injection of uranium, resulting from preferential leaching of ${ }^{234} \mathrm{U}$ during the hydrothermal alteration of rocks. In fact, in continental environments, Kupstov and Cherdyntsev (1969) have found a mean isotopic ${ }^{234} \mathrm{U} / 238 \mathrm{U}$ ratio of 1.34 , but it ranges from 1.04 to 2.25 . Moreover, the situation is more complex in deep sea as the fluid involved in the hydrothermal circulation is seawater which is relatively uranium rich $(3 \mu \mathrm{g} / \mathrm{l})$ and has an isotopic ratio of 1.14. Rydell and Bonatti (1973) have questioned the use of the ${ }^{234} \mathrm{U} /{ }^{238} \mathrm{U}$ ratio in deciding between the two origins, since they found in deposits of unambiguously hydrothermal origin uranium with a ratio close to that of seawater. Mangini and Dominik (1979), on the contrary, found uranium that was certainly provided by seawater in the sapropelic layers of the eastern Mediterranean to have ${ }^{234} \mathrm{U} /{ }^{238} \mathrm{U}$ ratios higher than 1.14 or lower than 1.00 . This was explained by these authors as resulting from the mobility of in situ produced ${ }^{234} \mathrm{U}$.

The mechanisms by which uranium is introduced into deep sea sediments must reflect the chemical properties of the element. In normal, oxidizing, deep-water conditions, uranium is soluble. To obtain large concentrations, it is necessary to have a reducing environment where the redox potential is sufficiently low to reduce the soluble $\mathrm{U}^{6+}$ to the relatively insoluble $\mathrm{U}^{4+}$. This may occur in anoxic basins as a result of high organic matter content and/or special hydrographical conditions (Veeh, 1967).

Uranium may also be scavenged from seawater by manganese and iron hydroxide precipitation. This mechanism can take place in regions of hydrothermal discharge, resulting in the mixture of three possible uranium sources: that from fresh seawater, that from sea- 
water after its hydrothermal path, and that from altered volcanic rocks. The resulting uranium concentrations and ${ }^{234} U /{ }^{238} U$ ratios will essentially depend on the relative proportions of the three sources (Bonatti et al., 1971). Thus, uranium origin cannot be uniquely defined by its isotope ratio alone; other information on the physico-chemical conditions of the environment must be considered.

Let us first examine the possible occurrence of local anoxic conditions in the mounds area during uranium injection. Anoxic environments can be produced in some oceanic basins by the oxidation of organic matter, which consumes the dissolved oxygen in seawater, releasing $\mathrm{CO}_{2}$ that is depleted in carbon 13 as compared to the $\mathrm{CO}_{2}$ dissolved in seawater (Craig, 1970; Kroopnick et al., 1970; Duplessy, 1972). We analyzed benthic foraminifers in the upper 3 meters of Hole 506D to detect the possible occurrence of a reducing environment at the time of deposition of the uranium excess and noted the following:

1) The continuous presence of benthic foraminifers in the sediment indicates that conditions at the site have never been entirely anoxic during the last 30,000 years, since these animals require some oxygen to live.

2) The $\delta^{18} \mathrm{O}$ and $\delta^{13} \mathrm{C}$ isotope values of the benthic foraminifer genus Uvigerina (Fig. 4) are very similar to those measured by Shackleton (1977) in the Panama Basin and by us in the Southern Indian Ocean (Duplessy, unpublished)-both areas far from any hydrothermal influence.

We thus conclude that the environment at the deep water-sediment interface remained well oxygenated during the time that uranium was being deposited in the sedimentary column. This agrees with what is known about deep oceanic circulation in the Panama Basin. Deep water enters the Panama Basin through the Ecuador Trench and the East Sill of the Carnegie Ridge with a mean flow rate of $35 \mathrm{~cm} / \mathrm{s}$; this allows rapid replacement of the deep water mass in less than 50 to 100 years (Lonsdale, 1977b). The geothermal area of the Galapagos Spreading Center is responsible for this short residence time of deep waters because the high heat flow generates an upward convection (Laird, 1971). A dense spillover flow can episodically cascade more than 500 meters down the north flank of the Carnegie Ridge, where traces of erosion and dune formations indicate that this current activity dates from the middle Pliocene (Lonsdale and Malfait, 1974). When the hydrothermal activity, and therefore the upward convection, was higher than it is today, this circulation pattern could only have been enhanced.

\section{Manganese Deposit}

Manganese oxide $\left(\mathrm{MnO}_{2}\right)$ is a well-defined phase recovered in Holes 507D and 509B (Leg 70) and Site 424 (Leg 54) as small fragments or plates. These fragments are probably pieces of large crusts broken by the coring operations.

They are particularly abundant in Hole 509B where they may be in correct stratigraphic position in the first core between $120 \mathrm{~cm}$ depth in the uppermost pelagic

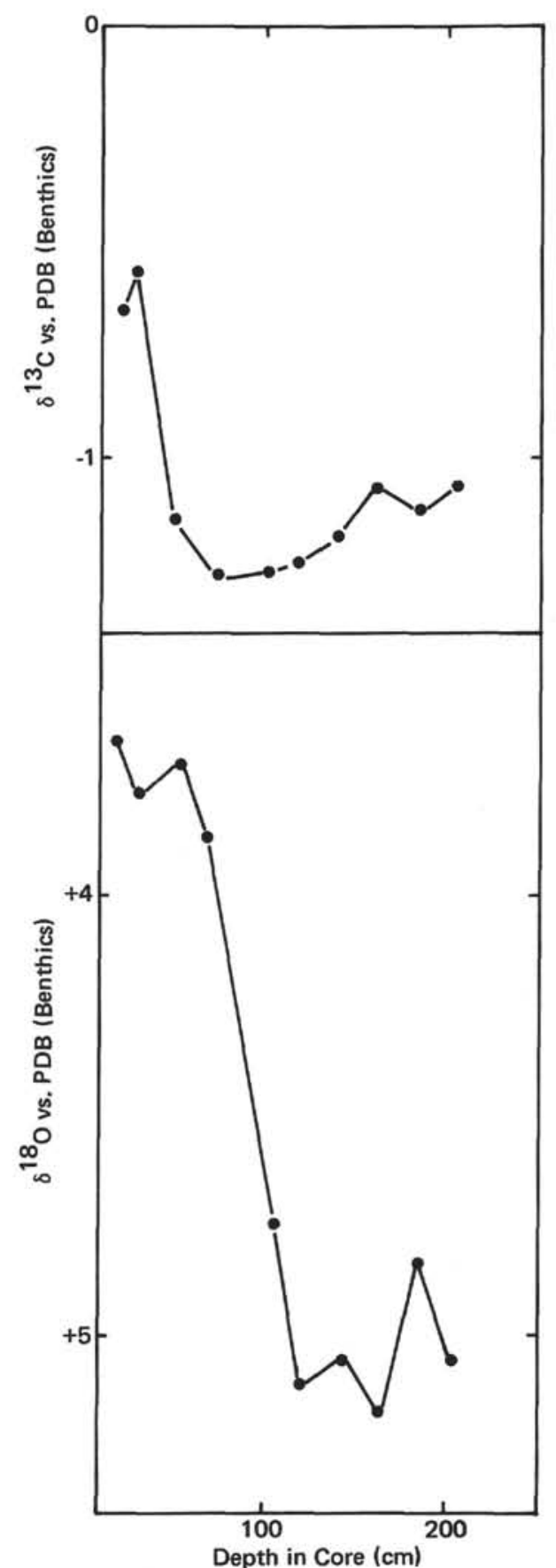

Figure 4. Carbon and oxygen isotope composition of the benthic foraminiferal genus Uvigerina in the upper part of Hole 506D.

sediment and the top of the hydrothermal nontronitic clay. On the other hand, the Mn deposits at 30 and 80 $\mathrm{cm}$ depths in this first core may either be in place or represent pollution from above. In other cores from the same hole, Mn-oxide crusts may indeed be a contaminant from the upper levels as they are always found at the top of the cores. At Site 424, they have been recovered in Holes 424, 424A, and 424B, scattered in the cores without clear stratigraphic sequence.

A dozen fragments have been analyzed for their radionuclide content-five from Hole 509B and seven 
from Hole 424, both holes being from the same mound. Results are given Tables 2 and 3 , respectively.

All of the samples show a ${ }^{230} \mathrm{Th}$ deficit with respect to ${ }^{234} \mathrm{U}$. Therefore, "ages" of formation may be calculated by assuming that all ${ }^{230} \mathrm{Th}$ was formed in situ (righthand column of Tables 2 and 3 ).

Two modes of occurrence may be considered: chemical precipitation at the seawater-sediment interface (as, for example, the sulfide precipitates recently discovered on the Pacific Rise at $21^{\circ} \mathrm{N}$ (Francheteau et al., 1979) or precipitation within a pre-existing sediment (as at least part of the Mn-rich FAMOUS deposit [Lalou et al., 1977]).

The lithologic description of Hole 509B suggests $\mathrm{MnO}_{2}$ precipitation in a pre-existing sediment, since there are only $110 \mathrm{~cm}$ of normal pelagic sediment above the Mn deposit, which is itself directly resting on the hydrothermal clay. If we take the sedimentation rate there to be the same as in Hole $506 \mathrm{C}-$ i.e., $4.9 \mathrm{~cm} / \mathrm{k} . \mathrm{y}$. -an age of 22,000 years is found for the end of the Mn event. This is exactly the age that we found for the upper $\mathrm{MnO}_{2}$ crust (Sample 509B-1-1, 133-135 cm), which is $10 \mathrm{~cm}$ under the interface between the Mn deposit and the upper pelagic sediment. The first three dates for $\mathrm{MnO}_{2}$ deposition obtained in this hole $(22,000,43,500$ and 51,000 years) are in accord with depth in the sedimentary column: the 22,000 years is in a sediment of 27,000 years, the 43,500 and 51,000-year-old crust are, respectively, in sediments that are 52,000 and 63,000 years old. The increase in the difference between the measured and calculated ages may indicate either a high- er sedimentation rate than that we used or coring disturbance. The two other dates $(30,000$ and 48,000 years) obtained for deeper samples in the same hole indicate probable contamination during coring operations as they are found on the top of Core 2. It would certainly be interesting to make a detailed chronology in Core 1 between 110 and $270 \mathrm{~cm}$ depth (i.e., theoretically between 22,000 and 55,000 years) and on the manganese fragments found between $380 \mathrm{~cm}$ and $430 \mathrm{~cm}$ (i.e., theoretically between 77,000 and 87,000 years) to see whether the deposition took place just after the nontronitic event and to see whether it was continuous or episodic.

The Mn samples from Hole 424 are not in good stratigraphic sequence. This may be attributed to drilling disturbance. Consequently it does not seem possible to discuss the relationships between ages and depth of occurrence of the samples.

One major fact is that in Hole 424, a number of Mn samples are younger than 10,000 years. Curiously enough the same samples also present higher uranium concentrations.

Assuming that these ages are real and not artifacts, they indicate that this mound was active more recently than that drilled at nearby Hole 509B. This conclusion is confirmed by the absence of "upper pelagic sediment" above the hydrothermal deposit, though the sediment may have been lost during drilling operations.

Or the dates may simply be wrong. We have seen that uranium-rich solutions percolated through the upper sediment system at Hole 506C about 19,000 years ago. If uranium were added to the $\mathrm{Mn}$ oxide sometime after its

Table 2. Radiochemical analysis of Mn-oxide deposits in Hole 509B, Leg 70 DSDP.

\begin{tabular}{|c|c|c|c|c|c|c|c|}
\hline $\begin{array}{c}\text { Sample } \\
\text { (interval in } \mathrm{cm} \text { ) }\end{array}$ & $\begin{array}{l}{ }^{232} \mathrm{Th} \\
\text { (ppm) }\end{array}$ & $\begin{array}{l}{ }^{238} \mathrm{U} \\
(\mathrm{ppm})\end{array}$ & $\begin{array}{l}{ }^{234} U /{ }^{238} U \\
\text { (dpm/dpm) }\end{array}$ & $\begin{array}{c}{ }^{234} \mathrm{U} \\
(\mathrm{dpm} / \mathrm{g})\end{array}$ & $\begin{array}{l}{ }^{230} \mathrm{Th} \\
(\mathrm{dpm} / \mathrm{g})\end{array}$ & ${ }^{230} \mathrm{Th} /{ }^{234} \mathrm{U}$ & Age \\
\hline & & & & & & & \\
\hline & & \pm & & & & & \\
\hline & & $9 \pm$ & & & & & \\
\hline & & & & & & & \\
\hline & & & & & & $0.359 \pm 0.027$ & \\
\hline \multicolumn{8}{|c|}{$\begin{array}{l}\text { Note: When a residue was present, it was dissolved in } \mathrm{HF} \text { acid before analysis. } \\
\text { Sample } 509 \mathrm{~B}-1-1,133-135 \text { represents the internal layer }(1.5 \text {-mm thick) of a } 2 \text { to } 2.5 \text {-mm thick deposit. It is made of todorokite } \\
\text { and has very little insoluble residue. } \\
\text { Sample } 509 \mathrm{~B}-1-2,105-106 \text { is identical to the preceding one. } \\
\text { Sample } 509 \mathrm{~B}-2-1,12-13 \text { represents the internal layer of a small plate, } 2 \text { to } 3 \mathrm{~mm} \text { thick, made of todorokite, it has a significant } \\
\text { amount of insoluble residue after } \mathrm{HCl}(6 \mathrm{~N})+\mathrm{HNO}(7 \mathrm{~N}) \text { attack. } \\
\text { Sample } 509 \mathrm{~B}-2-1,22-25 \text { represents the } 2 \text {-mm thick internal layer from a small plate, } 3 \text { to } 4 \mathrm{~mm} \text { thick. } \\
\text { Sample } 509 \mathrm{~B}-2-1,44-45 \text { represents a complete plate, about } 1.3 \mathrm{~mm} \text { thick, characterized by the presence of iron and an insolu- } \\
\text { ble fraction. }\end{array}$} \\
\hline
\end{tabular}

Table 3. Radiochemical analysis of Mn deposits Hole 424, Leg 54.

\begin{tabular}{|c|c|c|c|c|c|c|c|}
\hline $\begin{array}{c}\text { Sample } \\
\text { (interval in } \mathrm{cm} \text { ) }\end{array}$ & $\begin{array}{l}{ }^{232} \mathrm{Th} \\
(\mathrm{ppm})\end{array}$ & $\begin{array}{l}{ }_{(\mathrm{238}} \mathrm{U} \\
(\mathrm{pm})\end{array}$ & $\begin{array}{l}{ }^{234} \mathrm{U} /{ }^{238} \mathrm{U} \\
(\mathrm{dpm} / \mathrm{dpm})\end{array}$ & $\begin{array}{c}{ }^{234} \mathrm{U} \\
(\mathrm{dpm} / \mathrm{g})\end{array}$ & $\begin{array}{c}230 \mathrm{Th} \\
(\mathrm{dpm} / \mathrm{g})\end{array}$ & ${ }^{230} \mathrm{Th} /{ }^{234} \mathrm{U}$ & Age \\
\hline Loose Mn, 1-1 $1^{\mathrm{a}}$ & $0.51 \pm 0.17$ & $4.06 \pm 0.23$ & $1.170 \pm 0.070$ & $3.50 \pm 0.18$ & $0.40 \pm 0.04$ & $0.115 \pm 0.013$ & $13,500 \pm 1,500$ \\
\hline $1, C^{b}$ & $0.21 \pm 0.0$ & $11.3 \pm 0.4$ & $1.171 \pm 0.039$ & $9.73 \pm 0.038$ & $0.653 \pm 0.048$ & $0.067 \pm 0.005$ & $7,500 \pm 500$ \\
\hline $2, \mathrm{CC}^{\mathrm{c}}$ & $0.47 \pm 0.20$ & $21.7 \pm 0.7$ & $1.154 \pm 0.027$ & $18.4 \pm 0.6$ & $0.870 \pm 0.068$ & $0.047 \pm$ & $5,200 \pm$ \\
\hline $3-5,35-40^{\mathrm{d}}$ & n.d. & $1.07 \pm 0.09$ & $1.26 \pm 0.13$ & $0.99 \pm 0.07$ & $0.270 \pm 0.042$ & $0.273 \pm 0.048$ & $34,000 \pm 7,000$ \\
\hline $3-5,118-121^{\mathrm{e}}$ & 0.033 & $11.4 \pm 0.5$ & $1.092 \pm 0.039$ & $9.13 \pm 0.39$ & $0.355 \pm 0.029$ & $0.039 \pm 0.003$ & $4,300 \pm 300$ \\
\hline $4-1,10-12^{f}$ & $0.036 \pm 0.030$ & $10.6 \pm 0.7$ & $1.272 \pm 0.060$ & $10.0 \pm 0.6$ & $0.543 \pm 0.031$ & $0.054 \pm 0.005$ & $6,000 \pm$ \\
\hline Layer 1 & 0.14 & $3.97 \pm 0.19$ & & & 1.32 & & 6,000 \\
\hline Layer 2 & 0.15 & $9.6 \pm 0.4$ & $0.902 \pm 0.030$ & $6.37 \pm 0.27$ & $0.70 \pm 0.05$ & $0.110 \pm 0.009$ & $12,700 \pm 1,000$ \\
\hline
\end{tabular}

${ }^{a}$ Loose Mn, 1-1. Fragments of plates mixed with green hydrothermal mud; todorokite and birnessite identified.

Sample 424-1,CC. Two- to three-mm thick plate of pure todorokite; iron present.

c Sample 424-2,CC. Internal portion of a 3-mm thick plate; pure todorokite.

d Sample 424-3-5, 35-40. Plate made with alternating dense and powdered sublayers; todorokite and birnessite identified,

e Sample 424-3-5, 118-121. Dense portion (2- to $2.5-\mathrm{mm}$ thick) in a $3-\mathrm{mm}$ thick plate; pure todorokite.

f Sample 424-4-4, 10-12. Two- to three-mm thick plate; pure todorokite.

8 Sample 424-4-4, 40-42. Layer 1: Half of a 7- to 10-mm thick plate; birnessite with some todorokite; iron present. Layer 2: Second

half of same; about 4-mm thick; birnessite and todorokite, plus an insoluble residue. 
precipitation, this would result in an apparent younger age for the sample and might also explain the anomaly of Sample $424-4-4,40-42 \mathrm{~cm}$, the two parts of which have different ages-the younger being that with higher uranium content.

\section{Nontronitic Hydrothermal Deposit}

Because of the very small quantity of material available, only a few measurements were attempted on this deposit. The results are presented in Table 4 for Hole $424,424 \mathrm{~B}$, and 506C. Very weak radioactivities were found in the deposits. In Hole 424, no excess ${ }^{230} \mathrm{Th}$ exists, even in the first measured layer (Sample 424-1-1, $140-141 \mathrm{~cm}), 140 \mathrm{~cm}$ from the top. In Hole 424B, the two analyzed layers contain some excess of ${ }^{230} \mathrm{Th}$, which gives, between the two points, an apparent sedimentation rate of $2.7 \mathrm{~cm} / \mathrm{k} . \mathrm{y}$. (to be compared to the $2.4 \mathrm{~cm}$ / k.y. found in the upper pelagic sediment); this may indicate that this nontronitic clay has not been submitted to important drilling disturbances. In Hole 506C, the excess of ${ }^{230} \mathrm{Th}$ in the two analyzed layers leads to a sedimentation rate of $5.9 \mathrm{~cm} / \mathrm{k}$.y. (to be compared to 4.9 $\mathrm{cm} / \mathrm{k} . \mathrm{y}$. in the upper sediment).

Given our uncertainty about the volume change of the sedimentary column on nontronitic transformation, those values are in good agreement and confirm the fact that the nontronitic clay represents a transformation of pre-existing pelagic sediment.

Since nontronite is formed in slightly reducing conditions (Harder, 1976; Corliss et al., 1978), in which uranium, if present in the hydrothermal solution, would precipitate, the fact that nontronite is uranium poor indicates that the hydrothermal solution responsible for the nontronite formation did not contain any uraniumhaving previously lost it.

\section{Basal Sediment}

In a previous study (Lalou and Brichet, 1980b), we showed that in Holes 424, 424A, and 424B, the basal sediment is highly enriched in uranium. To know how widespread this enrichment is in the mounds area, we studied radionuclides in the basal sediment from Hole $506 \mathrm{C}$, about $4 \mathrm{~km}$ northwest of Site 424 .

The results for Hole $506 \mathrm{C}$ are given in Table 5, and Table 6 gives the earlier measurements for Holes 424, $424 \mathrm{~A}$, and 424B, with some supplementary results.

The main characteristics of basal sediment from all four holes is the very large uranium enrichments, compared to normal pelagic sediments. These enrichments are illustrated Figure 5 where they are plotted against distance from the basement. Figure 6 shows the ${ }^{234} \mathrm{U} /$ ${ }^{238} \mathrm{U}$ ratio values. Because of poor sediment recovery at Site 424 , the distance figures are not as accurate for Holes 424, 424A, and 424B as for Hole 506C. Nevertheless, the relative positions of samples in each hole are quite good. Higher uranium enrichment is found about 6 meters from basement.

In Hole 506C, the uppermost sample (506C-3-3, $53-54 \mathrm{~cm}$ ) is not characteristic of basal sediment because it occurred between two thick nontronitic layers. If we accept 90,000 years as the age of the end of nontronite formation and $4.9 \mathrm{~cm} / \mathrm{k} . \mathrm{y}$. as the sedimentation rate, then this sample-being $700 \mathrm{~cm}$ below the $90,000-$ year limit-would have been deposited about 230,000 years ago. Such an age would explain the slight excess of ${ }^{230} \mathrm{Th}$ found. In the other eight samples from the same hole, ${ }^{230} \mathrm{Th}$ is in equilibrium with ${ }^{234} \mathrm{U}$. This is to be expected, since Sample $506 \mathrm{C}-5-1,82-83 \mathrm{~cm}$, the highest (youngest) of the eight, was deposited 110,000 years earlier than Sample 506C-3-3, 53-54 cm (i.e., 340,000 years ago). This equilibrium also shows that uranium enrichment took place more than 300,000 years ago.

At Site $424,{ }^{230} \mathrm{Th}$ is also in equilibrium with ${ }^{234} \mathrm{U}$, but no precise chronology can be attempted because the positions of the samples are not well defined.

In summary, the sediments below the nontronitic layer were deposited between 600,000 and 300,000 years ago, and an injection of uranium occurred earlier than about 300,000 years ago.

\section{TENTATIVE GEOCHRONOLOGICAL RECONSTRUCTION}

From direct observation of the mounds fields with DSRV Alvin and from heat flow studies, Williams et al. (1979) proposed several models for mound formation which we can consider in light of our results. In these models, two periods have been proposed for the initiation of the hydrothermal sequence:

1) About 300,000 years ago. This estimate is based on the thickness of sediments between the basement and the lowermost nontronitic clay, a mean sedimentation rate of $5 \mathrm{~cm} / \mathrm{k} . y$. , and an age of 600,000 years for the basement. In this model, the mounds began to form 7 to $11 \mathrm{~km}$ south of the ridge axis.

2) Less than 130,000 years ago. This estimate is based on the fact that at present no abnormal heat flux is measured and no mound formation is found north of the 17 $\mathrm{km}$ south of the spreading center scarp. If the mounds began to develop only when the underlying crust was 17

Table 4. Radiochemistry in green nontronitic clay in Holes 424 and 424B (Leg 54) and Hole 506C (Leg 70).

\begin{tabular}{|c|c|c|c|c|c|c|c|c|}
\hline $\begin{array}{c}\text { Sample } \\
\text { (interval in } \mathrm{cm} \text { ) }\end{array}$ & $\begin{array}{l}{ }^{238} \mathrm{U} \\
(\mathrm{ppm})\end{array}$ & $\begin{array}{l}{ }^{232} \mathrm{Th} \\
\text { (ppm) }\end{array}$ & $\begin{array}{l}{ }^{234} \mathrm{U} /{ }^{238} \mathrm{U} \\
(\mathrm{dpm} / \mathrm{dpm})\end{array}$ & $\begin{array}{c}{ }^{234} \mathrm{U} \\
(\mathrm{dpm} / \mathrm{g})\end{array}$ & $\begin{array}{c}{ }^{230} \mathrm{Th} \\
(\mathrm{dpm} / \mathrm{g})\end{array}$ & $\begin{array}{c}{ }^{230} \mathrm{Th}_{\text {excess }} \\
(\mathrm{dpm} / \mathrm{g})\end{array}$ & $\begin{array}{c}\text { Clays } \\
(\%)\end{array}$ & $\begin{array}{c}{ }^{230} \mathrm{Th} \\
\text { (for } 100 \% \text { clays) }\end{array}$ \\
\hline $424-1-1,140-141$ & $0.54 \pm 0.04$ & $0.09 \pm 0.01$ & $0.997 \pm 0.071$ & $0.396 \pm 0.028$ & $0.39 \pm 0.02$ & & & \\
\hline $424-2-1,100-101$ & $0.35 \pm 0.03$ & $0.020 \pm 0.005$ & $1.27 \pm 0.11$ & $0.33 \pm 0.03$ & $0.22 \pm 0.01$ & & & \\
\hline 424B-1-2, 78-79 & $0.60 \pm 0.03$ & $1.69 \pm 0.19$ & $1.085 \pm 0.052$ & $0.48 \pm 0.02$ & $4.6 \pm 0.4$ & $4.12 \pm 0.42$ & 20.2 & 21.3 \\
\hline $424 \mathrm{~B}-2-4,33-34$ & $0.20 \pm 0.01$ & $0.35 \pm 0.03$ & $1.198 \pm 0.084$ & $0.18 \pm 0.01$ & $0.69 \pm 0.03$ & $0.51 \pm 0.04$ & 16.3 & 2.73 \\
\hline $506 C-3-1,60-61$ & $0.42 \pm 0.03$ & $1.28 \pm 0.014$ & $1.026 \pm 0.091$ & $0.32 \pm 0.02$ & $0.61 \pm 0.05$ & $0.29 \pm 0.07$ & 21.5 & 1.33 \\
\hline $506 C-4-1,135-136$ & $0.13 \pm 0.01$ & $0.13 \pm 0.03$ & $0.91 \pm 0.12$ & $0.090 \pm 0.009$ & $0.148 \pm 0.014$ & $0.054 \pm 0.026$ & 7 & 0.61 \\
\hline
\end{tabular}


Table 5. Radiochemistry in the basal sediment, Hole 506C, Leg 70.

\begin{tabular}{lcccccccc}
\hline $\begin{array}{c}\text { Sample } \\
\text { (interval in cm) }\end{array}$ & $\begin{array}{c}\mathrm{CaCO}_{3} \\
(\%)\end{array}$ & $\begin{array}{c}{ }^{238} \mathrm{U} \\
(\mathrm{ppm})\end{array}$ & $\begin{array}{c}{ }^{238} \mathrm{U} \\
(\mathrm{ppm})^{\mathrm{a}}\end{array}$ & $\begin{array}{c}{ }^{232} \mathrm{Th} \\
(\mathrm{ppm})\end{array}$ & $\begin{array}{c}{ }^{232} \mathrm{Th} \\
(\mathrm{ppm})\end{array}$ & $\begin{array}{c}{ }^{2}{ }^{234} \mathrm{U} /{ }^{238} \mathrm{U} \\
(\mathrm{dpm} / \mathrm{dpm})\end{array}$ & $\begin{array}{c}{ }^{234} \mathrm{U} \\
(\mathrm{dpm} / \mathrm{g})\end{array}$ & $\begin{array}{c}230_{\mathrm{Th}} \\
(\mathrm{dpm} / \mathrm{g})\end{array}$ \\
\hline $3-3,53-54$ & 45 & $0.88 \pm 0.06$ & $1.6 \pm 0.1$ & $1.1 \pm 0.2$ & $2.0 \pm 0.3$ & $1.26 \pm 0.10$ & $0.82 \pm 0.5$ & $1.23 \pm 0.07$ \\
$5-1,82-83$ & 72.6 & $2.14 \pm 0.07$ & $7.8 \pm 0.3$ & $0.60 \pm 0.08$ & $2.3 \pm 0.3$ & $1.045 \pm 0.043$ & $1.65 \pm 0.06$ & $1.81 \pm 0.07$ \\
$6-1,52-53$ & 79.5 & $1.80 \pm 0.09$ & $8.8 \pm 0.4$ & $0.53 \pm 0.09$ & $2.6 \pm 0.5$ & $0.978 \pm 0.057$ & $1.30 \pm 0.07$ & $1.27 \pm 0.06$ \\
$6-2,52-53$ & 79.7 & $3.55 \pm 0.10$ & $17.5 \pm 0.5$ & $0.53 \pm 0.18$ & $2.6 \pm 0.8$ & $1.019 \pm 0.035$ & $2.66 \pm 0.08$ & $2.67 \pm 0.15$ \\
$7-1,100-101$ & 79.4 & $10.3 \pm 0.3$ & $50.0 \pm 1.6$ & $1.15 \pm 0.12$ & $5.6 \pm 0.6$ & $1.094 \pm 0.030$ & $8.30 \pm 0.26$ & $9.06 \pm 0.23$ \\
$7-2,38-39$ & 72.7 & $24.7 \pm 0.7$ & $90.6 \pm 2.7$ & $1.19 \pm 0.25$ & $4.4 \pm 0.9$ & $1.026 \pm 0.021$ & $18.7 \pm 0.6$ & $17.2 \pm 0.6$ \\
$7-2,100-101$ & 73.7 & $25.8 \pm 1.3$ & $98.1 \pm 4.8$ & $0.80 \pm 0.15$ & $3.0 \pm 0.6$ & $1.051 \pm 0.025$ & $19.9 \pm 1.0$ & $20.0 \pm 1.1$ \\
$8-2,30-31$ & 76.1 & $13.9 \pm 0.7$ & $58.1 \pm 3.0$ & n.d. & - & $1.049 \pm 0.034$ & $10.7 \pm 0.6$ & $9.9 \pm 0.6$ \\
$8-2,136-137$ & 79.5 & $8.55 \pm 0.57$ & $41.7 \pm 2.8$ & $0.61 \pm 0.10$ & $3.0 \pm 0.5$ & $1.026 \pm 0.051$ & $6.5 \pm 0.4$ & $6.4 \pm 0.3$ \\
\hline
\end{tabular}

a $\mathrm{On} \mathrm{a} \mathrm{CaCO}_{3}$-free basis.

Table 6. Radiochemistry in the basal sediments, Holes 424, 424A, and 424B, Leg 54.

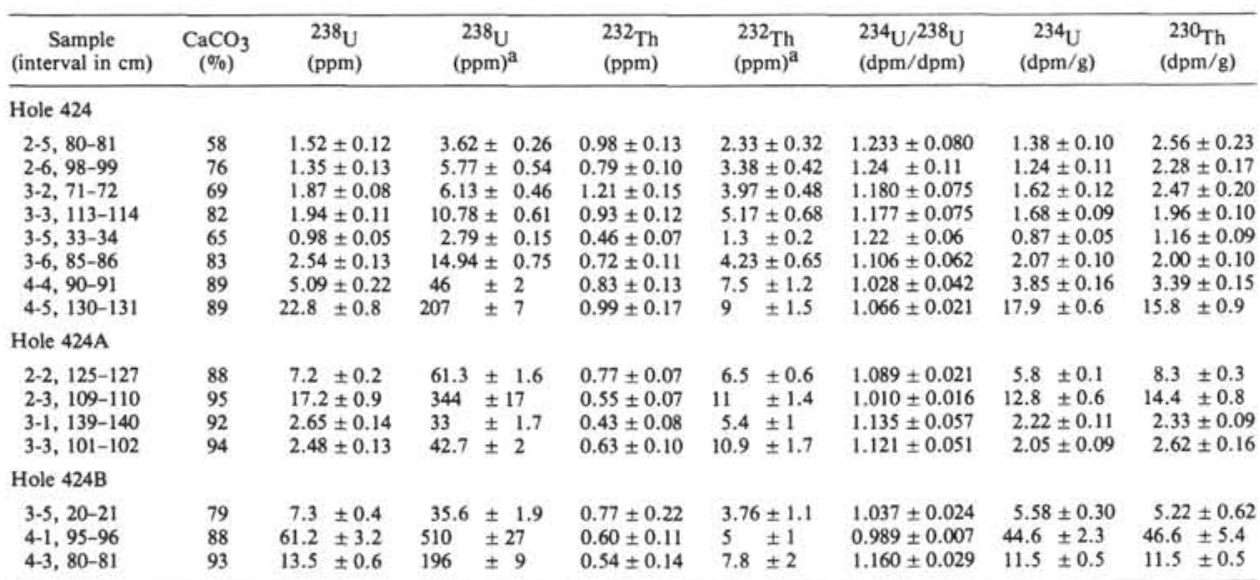

a $\mathrm{On} \mathrm{a} \mathrm{CaCO}_{3}$-free basis.

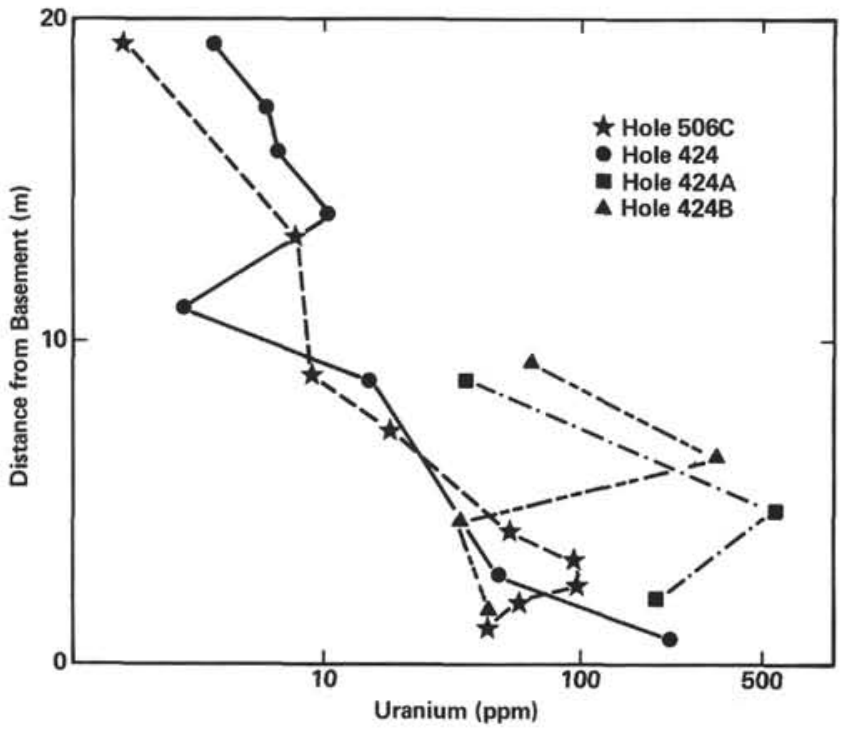

Figure 5. Uranium-enrichment repartition in basal sediment at Holes $506 \mathrm{C}, 424,424 \mathrm{~A}$, and $424 \mathrm{~B}$. (Uranium values are $\mathrm{CaCO}_{3}$-free values. The vertical scale is the distance from basement.)

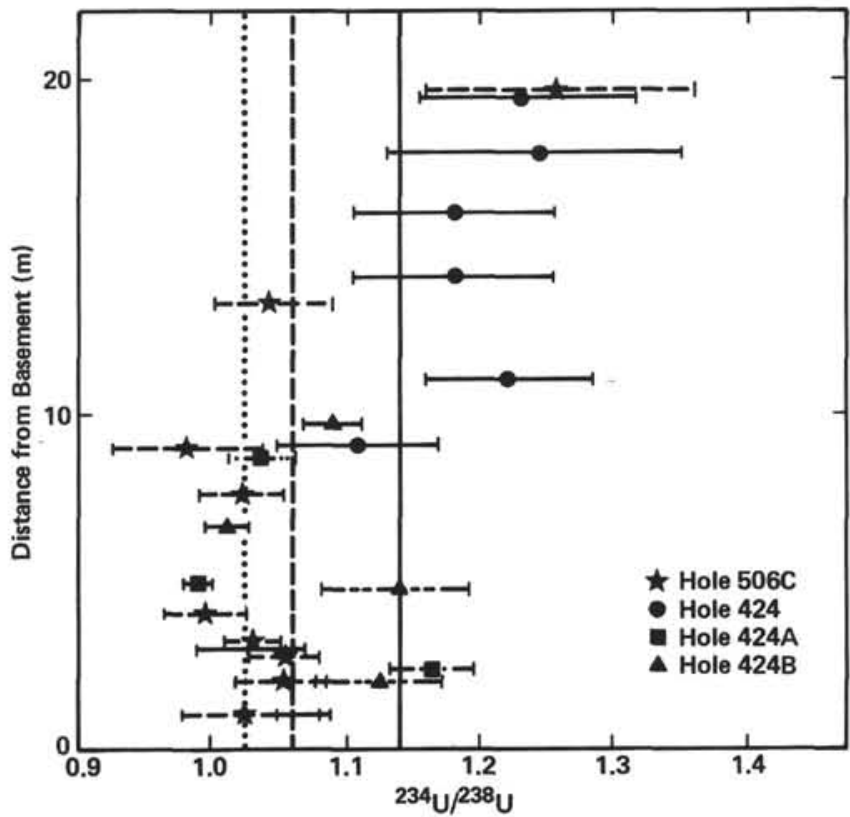

Figure 6. Isotope ratio of uranium in the basal sediment. (Full line indicates the present 1.14 seawater ratio; dashed line is the present ratio for uranium deposited from seawater 300,000 years ago; points are for the same uranium deposited 600,000 years ago.) 
$\mathrm{km}$ south of the ridge-that is on a basement about 500,000 years old - then the mounds drilled at Site 424 would be less than 130,000 years old.

The principal dates from 600,000 years to present that we have established are (Fig. 7): (1) a uranium injection earlier than 300,000 years before present; (2) an earlier occurrence of nontronite in a 300,000-year-old sediment and its latest occurrence in a sediment 90,000 years old; (3) $\mathrm{MnO}_{2}$ deposition from 60,000 to 20,000 years ago; and (4) uranium injection 19,000 years ago in a normal oxygenated sediment accumulating at a rate of $4.9 \mathrm{~cm} / \mathrm{k} . \mathrm{y}$.

The injection of uranium in the basal sediment is hydrothermal in origin since ${ }^{234} \mathrm{U} /{ }^{238} \mathrm{U}$ ratios (Fig. 6) in a great number of samples are incompatible with seawater uranium deposited more than 300,000 years ago (Lalou and Brichet, 1980b). The greatest enrichments (more than $10 \mathrm{ppm}$ ) are localized in the first 10 meters from the basement. So a single injection of uranium may be postulated to have taken place between 400,000 years ago-the age of the youngest uranium enriched sediment-and 300,000 years ago-the time needed to have ${ }^{230} \mathrm{Th}$ achieve equilibrium with ${ }^{234} \mathrm{U}$. This period

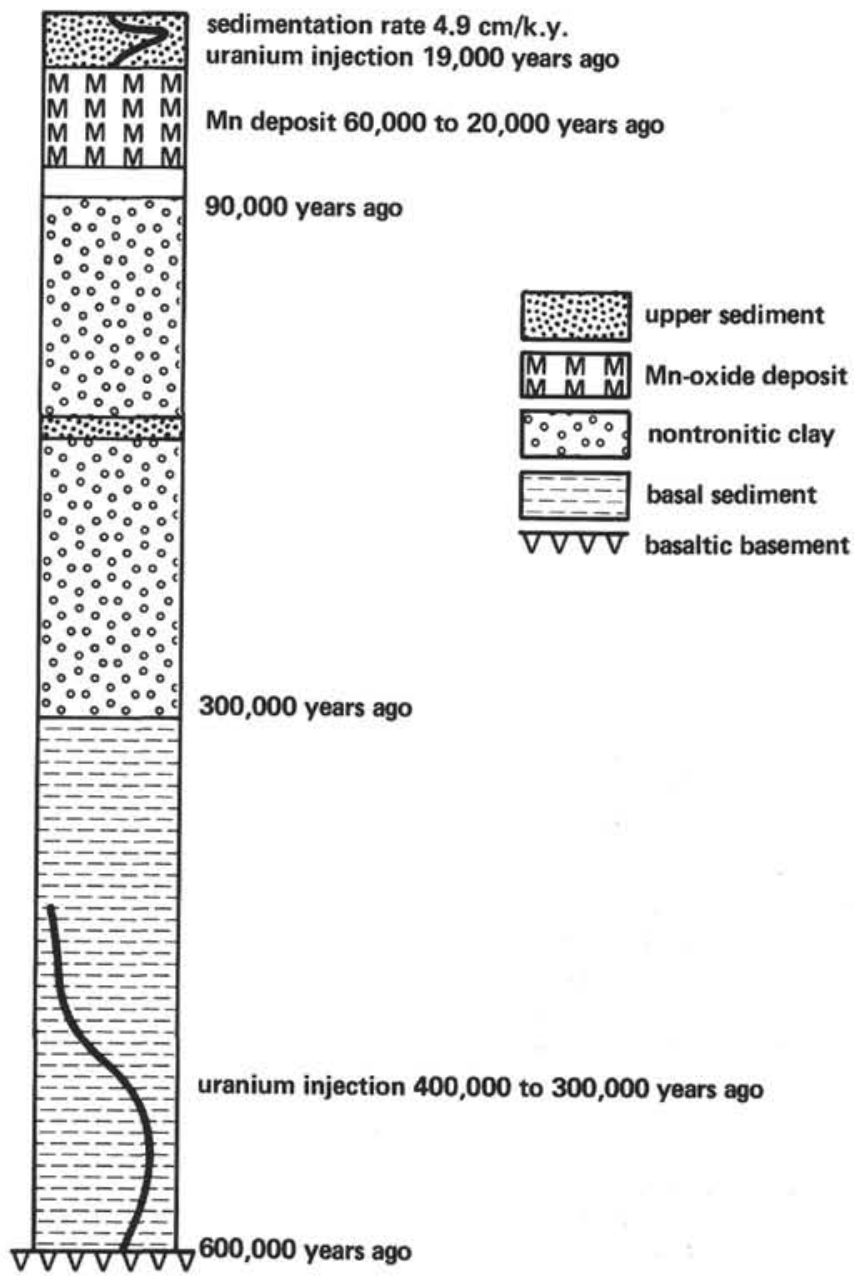

Figure 7. Schematic diagram of a composite core with dates obtained for different phases. probably represents the initiation of the hydrothermal system.

Evidence from isotopes indicates that hydrothermal nontronite results from the transformation of a preexisting sediment rather than from direct precipitation. The upper limit has been dated at about 90,000 years. Two mechanisms may be responsible for this formation: the rapid impregnation of the pre-existing sedimentary column at about 90,000 years before present or the slow transformation of pelagic ooze as it settled particle by particle between 300,000 and 90,000 years ago. In the first case, it would be difficult to explain why the whole sedimentary sequence from 600,000 to 90,000 years was not modified. In the second case, since nontronite is formed in slightly reducing conditions (Harder, 1976; Corliss et al., 1978), one would expect to find it forming progressively some tens of centimeters below the seawater-sediment interface. During the transit in deeper sediments, uranium was scavenged from the hydrothermal solution. This possibility is supported by two facts: first, the nontronite shows excess ${ }^{230} \mathrm{Th}$ compatible with its depth of occurrence. In a more instantaneous reaction, thorium isotopes would have been mobilized and redistributed. Second, the uranium injection occurred more than 300,000 years ago. In mounds such as those from Site 506 (if the mound top was drilled effectively) it appears that the hydrothermal process ended 90,000 years ago since normal pelagic sedimentation has covered the nontronitic layer.

In mounds from Site 424 and Site 509, manganese oxide precipitated on top of, and probably after, the formation of nontronite. This precipitation took place under oxidizing conditions at the seawater-sediment interface (Lynn and Bonatti, 1965). From the position and ages of the Mn encrustations in Hole 509, we are led to conclude that they are also a modification of pre-existing sediment.

Two mechanisms have been suggested to account for the manganese oxide precipitation: Williams et al. (1979) suggested that manganese precipitation occurs at the limit between nontronitic and normal sediments and that the compound is continuously dissolved and reprecipitated.

Natland et al. (1979) suggested that the hydrothermal system, which was at first rock-dominated (leading to the precipitation of iron and silica), became waterdominated in a second phase (leading to the precipitation of manganese).

A third possibility would be a change in the hydrothermal flow. At the beginning the flow might have been sufficient to allow the manganese, in a highly reduced state, to escape into the open ocean without precipitating (as has been observed in the hydrothermal vents on the East Pacific Rise, $21^{\circ} \mathrm{N}$ ). When the flow slowed down, the manganese precipitated in the oxidized upper part of the sedimentary column.

According to Williams' hypothesis, Mn formation must have stopped at the same time as nontronite formation-that is, 90,000 years ago. According to the other two hypotheses, the Mn deposit would be younger than the nontronite formation. In light of the dates we ob- 
tained for Mn-oxide formation and the stratigraphic position of the $\mathrm{MnO}$ relative to the nontronite we favor the last two hypotheses.

The uranium injection in the upper sediment cannot have come from below as it would have had to pass through a thick sequence of reducing sediment in which it would have precipitated. Thus, it must have come from seawater. We found this uranium enrichment in a sediment capping the hydrothermal deposit, and probably injected after the hydrothermal circulation had stopped. In this case, a temporary inversion of flow leading to an influx of seawater into the sediment may be assumed to have resulted from cooling at the site. Under the oxidized few tens of centimeters in which the benthic community develops, reducing conditions may be sufficient to allow the deposition of uranium, provided an influx of seawater becomes possible. The shape of the uranium profiles, the ${ }^{234} \mathrm{U} /{ }^{238} \mathrm{U}$ ratios (Fig. 3) - which are in relatively good agreement with the values of present seawater-as well as the "age" of this uranium support the hypothesis of an influx of uranium from seawater. Nevertheless, many more measurements are necessary to refine our speculations.

\section{ACKNOWLEDGMENTS}

The preparation of foraminifers for isotope studies was made by $\mathrm{J}$. Antignac and mass spectrometer measurements by B. Le Coat. We thank Roger Hekinian for having introduced us to the wonderland of Galapagos hydrothermalism, Laurent Labeyrie for stimulating discussions, and Teh Lung $\mathrm{Ku}$ and Jose Honnorez who reviewed this chapter. Financial support from C.N.R.S., C.E.A., and I.P.O.D. France Grant is gratefully acknowledged.

\section{REFERENCES}

Bender, M., Broecker, W., Gornitz, V., Middel, U., Kay, R., Sun, S., and Biscaye, P., 1971. Geochemistry of three cores from the East Pacific Rise. Earth Planet. Sci. Lett., 12:425-433.

Bonatti, E., Fisher, D. E., Joensuu, O., and Rydell, H. S., 1971. Postdepositional mobility of some transition elements, phosphorus, uranium and thorium in deep sea sediments. Geochim. Cosmochim. Acta, 35:189-201.

Bostrom, K., and Rydell, H., 1979. Geochemical behavior of U and Th during exhalative sedimentary processes. In Lalou, C. (Ed.), Colloque Intern. C.N.R.S. 289: La Genèse des Nodules de Manganèse: Paris (C.N.R.S.), 151-166.

Broecker, W. S., and Ku, T. L., 1969. Caribbean cores P. 6304-8, P. 6304-9: New analysis of absolute chronology. Science, 166: 404-406.

Broecker, W. S., and Van Donk, J., 1970. Insolation changes, ice volumes and the O-18 record in deep sea cores. Rev. Geophys. Space Phys., 169-196.

CLIMAP Project Members, 1976. The surface of the ice age earth. Science, 191:1131-1137.

Corliss, J. B., Dymond, J., Gordon, I., Edmond, J. M., Von Herzen, R. P., Ballard, R. D., Green, K., Williams, D., Bainbridge, A., Crane, K., and van Andel, Tj. H., 1979. Submarine thermal springs on the Galapagos Rift. Science, 203:1073-1083.

Corliss, J. B., Lyle, M., Dymond J., and Crane, K., 1978. The chemistry of hydrothermal mounds near the Galapagos rift. Earth Planet. Sci. Lett., 40:12-24.

Craig, H., 1970. Abyssal carbon 13 in the South Pacific. J. Geophys. Res., 75:691-695.

Detrick, R. S., Williams, D. L., Mudie, J. D., and Sclater, J. G., 1974. The Galapagos Spreading Center: Bottom water temperatures and significance of geothermal heating. Geophys. J. R. Astron. Soc., 38: 627-637.

Duplessy, J. C., 1972. La geochimie des isotopes stables du carbone dans la mer [Thèse Dr]. Univ. Paris VI.

1978. Isotope studies. In Gribbin, J. B. (Ed.), Climatic Changes: Cambridge (Cambridge University Press), pp. 46-67.
Dymond, J., and Veeh, H. H., 1975. Metal accumulation rates in the southeast Pacific and the origin of metalliferous sediments. Earth Planet. Sci. Lett., 28:13-22.

Emiliani, C., 1955. Pleistocene temperatures. J. Geol., 63:538-578.

Fisher, D. E., and Boström, K., 1969. Uranium rich sediments on the East Pacific Rise. Nature, 224:64-65.

Francheteau, J., Needham, H. D., Choukroune, P., Juteau, T., Seguret, M., Ballard, R. D., Fox, P. J., Normak, W., Carranza, A., Cordoba, D., Guerrero, J., Ranguin, C., Bougault, H., Cambon, P., and Hekinian, R., 1979. Massive deep sea sulphide ore deposits discovered on the East Pacific Rise. Nature, 277:523-528.

Harder, H., 1976. Nontronite synthesis at low temperatures. Chem. Geol., 18:169-180.

Hekinian, R., Rosendahl, B. R., Cronan, D. S., Dmitriev, Y., Fodor, R. V., Goll, R. M., Hoffert, M., Humphris, S. E., Mattey, D. P. Natland, J., Petersen, N., Roggenthen, W., Schrader, E. L., Srivastava, R. R., and Warren, N., 1978. Hydrothermal deposits and associated basement rocks from the Galapagos Spreading Center. Oceanol. Acta, 1:473-482.

Holmes, C. W., Osmond, J. K., and Goodel, H. G., 1968. The geochronology of foraminiferal ooze deposits in the "Southern Ocean." Earth Planet. Sci. Lett., 4:368-374.

Klinkhammer, G., Weiss, R. F., and Bender, M., 1977. Hydrothermal manganese in the Galapagos Rift. Nature, 269:319-320.

Klitgord, K. D., and Mudie, J. D., 1974. The Galapagos Spreading Centre: A near-bottom geophysical survey. Geophys. J. R. Astron. Soc., 38:563-586.

Kroopnick, P., Deuser, W. G., and Craig, H., 1970. Carbon 13 measurements on dissolved inorganic carbon at the north Pacific (1969) Geosecs station. J. Geophys. Res., 75:7668-7671.

Ku, T. L., 1966. Uranium series disequilibrium in deep sea sediments [Ph.D. dissert.]. Columbia University, New York.

1969. Uranium series isotopes in sediments from the Red Sea hot brines area. In Degens, E. T., and Ross, D. A. (Eds.), Hot Brines and Recent Heavy Metal Deposits in the Red Sea: New York (Springer-Verlag), pp. 512-524.

1976. The uranium series methods of age determination. Ann. Rev. Earth Planet. Sci., 4:347-379.

Kupstov, V. M., and Cherdynstev, V. V., 1969. The decay product of uranium and thorium in active volcanism in USSR (trans. from Geokhimiya, 6:643-658). Geochemistry Intern., 6:532-545.

Laird, N., 1971. Panama basin deep water: Properties and circulation. J. Mar. Res., 29(3):226-234.

Lalou, C., and Brichet, E., 1980a. Les dépôts de sulfures hydrothermaux de la dorsale E. Pacifique à $21^{\circ} \mathrm{N}$ : Etude des isotopes de la famille de l'uranium. C.R. Acad. Sci. Paris, 290D:819-822.

, 1980b. Anomalously high uranium contents in the sediments under Galapagos hydrothermal mounds. Nature, 284:251253.

Lalou, C., Brichet, E., Ku, T. L., and Jehanno, C., 1977. Radiochemical, scanning electron microscope (SEM) and X-ray dispersive energy (EDAX) studies of "FAMOUS" hydrothermal deposit. Mar. Geol., 24:245-258.

Lonsdale, P., 1977a. Deep tow observations at the mound abyssal hydrothermal field, Galapagos Rift. Earth Planet. Sci. Lett., 36: 92-110.

, 1977b. Inflow of bottom water to the Panama basin. Deep Sea Res., 24:1065-1101.

Lonsdale, P., and Malfait, B., 1974. Abyssal dunes of foraminiferal sand on the Carnegie Ridge. Geol. Soc. Am. Bull., 85:1697-1712.

Lynn, D. C., and Bonatti, E., 1965. Mobility of manganese and diagenesis of deep sea sediments. Mar. Geol., 3:457-474.

Mangini, A., and Dominik, J., 1979. Late Quaternary sapropel on the Mediterranean Ridge: $U$ budget and evidence of low sedimentation rates. Sediment. Geol., 23:113-125.

Mo, T., Suttle, A. D., and Sackett, W. M., 1973. Uranium concentration in marine sediments. Geochim. Cosmochim. Acta, 37:35-51.

Natland, J. H., Rosendahl, B., Hekinian, R., Dmitriev, Y., Fodor, R. V., Goll, R. M., Hoffert, M., Humphris, S. E., Mattey, D. P., Petersen, N., Roggenthen, W., Schrader, E. L., Srivastava, R. K., and Warren, N., 1979. Galapagos hydrothermal mounds: Stratigraphy and chemistry revealed by deep sea drilling. Science, 204: 613-616.

Pisias, N. G., 1976. Late Quaternary sediment of the Panama basin: Sedimentation rates, periodicities and controls of carbonate and opal accumulation. Geol. Soc. Am. Mem., 145:375-391. 
Rona, E., and Joensuu, O., 1974. Uranium geochemistry in the Black Sea. Mem. Am. Assoc. Pet. Geol., 20:570-572.

Rydell, H. S., and Bonatti, E., 1973. Uranium in submarine metalliferous deposits. Geochim. Cosmochim. Acta, 37:2557-2565.

Rydell, H. S., Kraemer, T., Boström, K., and Joensuu, O., 1974. Post-depositional injections of uranium rich solutions into East Pacific Rise sediments. Mar. Geol., 17:151-164.

Sclater, J. G., and Klitgord, K. D., 1973. A detailed heat flow, topographic and magnetic survey across the Galapagos Spreading Center at $86^{\circ}$ W. J. Geophys. Res., 78:6951-6975.

Sclater, J. G., Von Herzen, R. P., Williams, D. L., Anderson, R. N., and Klitgord, K., 1974. The Galapagos Spreading Centre: Heat Flow on the North flank. Geophys. J. R. Astron. Soc., 38: 609-626.

Scott, M. R., Scott, R. B., Rona, P., Butler, L. W., and Nalwak, A. J., 1974. Rapidly accumulating manganese deposits from the median valley of the Mid Atlantic Ridge. Geophys. Res. Lett., 1(8): 355-358.

Shackleton, N. J., 1977. Carbon 13 in Uvigerina: Tropical rain forest history and the equatorial Pacific carbonate dissolution cycles. In Anderson, N. R., and Malahoff, A. (Eds.), The Fate of Fossil Fuel $\mathrm{CO}_{2}$ in the Oceans: New York (Plenum), pp. 401-427.

Shackleton, N. J., and Opdyke, N. D., 1973. Oxygen isotopes and paleomagnetic stratigraphy of Equatorial Pacific Core V28-238: Oxygen isotope temperatures and ice volumes on a $10^{5}$ year scale. Quat. Res., 3:39-55.
1976. Oxygen isotope and paleomagnetic stratigraphy of Pacific Core V28-239, late Pliocene to latest Pleistocene. Mem. Geol. Soc. Am., 145:449-464.

Thompson, P. R., Bé, A. W. H., Duplessy, J. C., and Shackleton, N. J., 1979. Disappearance of pink pigmented Globigerinoides ruber at 120,000 years B.P. in the Indian and Pacific oceans. Nature, 280:554-558.

Turekian, K. K., and Bertine, K. K., 1971. Deposition of molybdenum and uranium along the major ocean ridge systems. Nature, 229:250-251.

Turekian, K. K., and Wedepohl, K. H., 1961. Distribution of the elements in some major units of the Earth's crust. Geol. Soc. Am. Bull., 72:175-192.

Veeh, H. H., 1967. Deposition of uranium from the ocean. Earth Planet. Sci. Lett., 3:145-150.

Veeh, H. H., and Boström, K., 1971. Anomalous ${ }^{234} U /{ }^{238} U$ on the East Pacific Rise. Earth Planet. Sci. Lett., 10:372-374.

Williams, D. L., Green, K., van Andel, Tj. H., Von Herzen, R. P., Dymond, J. R., and Crane, K., 1979. The hydrothermal mounds of the Galapagos Rift: Observations with DSRV Alvin and detailed heat flow studies. J. Geophys. Res., 84(B13):7467-7484.

Williams, D. L., Von Herzen, R. P., Sclater, J. G., and Anderson, R. N., 1974. The Galapagos Spreading Center: Lithospheric cooling and hydrothermal circulation. Geophys. J. R. Astron. Soc., 38: 587-608. 